\title{
Improving the business communication skills of postgraduate internal audit students: A South African teaching innovation
}

\section{AUTHORS:}

1. Kato Plant, Senior Lecturer, Department of Auditing, University of Pretoria, South Africa (corresponding author)

Postal address:

Faculty of Economic and Management Sciences, Department of Auditing, University of Pretoria, Pretoria, 0002

kato.plant@up.ac.za

2. Jana Slippers, Course Responsible Lecturer, Communication Management Division, Department Business Management, University of Pretoria, South Africa

Postal address:

Faculty of Economic and Management Sciences, Department of Communication Management, University of Pretoria, Pretoria, 0002

jana.slippers@up.ac.za

\begin{abstract}
This article reports on the introduction of a business communication course into the curriculum of postgraduate internal audit students at a higher education institution in South Africa. Internal auditors should have excellent verbal and written communication skills in performing value-adding assurance and consulting services to their engagement clients. A hands-on applied business communication course was developed in collaboration with a number of stakeholders to improve the communication skills of postgraduate internal audit students using the action research methodology. Data was gathered from these students to determine the benefits of an applied business communication course. The study found that a learning need had been addressed and that an applied business communication course has several benefits, such as promoting teamwork, building confidence, improving presentation skills and ultimately preparing postgraduate students for communicating effectively at work.
\end{abstract}

\section{KEYWORDS}

Business communication skills, internal auditing, internal audit education, experiential learning, action research 


\section{Introduction}

In recent years the demand on internal auditors to communicate more effectively in the business environment has increased significantly (Fourie, 2005; PwC, 2013; Smith, 2005). Reasons for the increased need for internal auditors to possess excellent communication skills are, among others, the impact of the changing global economy and technology on the role of the internal audit function (IAF) as well as the changing needs of management in organisations.

The role of the IAF in an organisation is to provide assurance and consulting services, adding value and improving the operations by evaluating the effectiveness of the business processes within the organisation (IIA, 2011) and communicating the results of the evaluation to various parties. This responsibility requires a variety of technical as well as behavioural skills, including communication skills. Internal auditors regularly interact with their clients or auditees, including management, staff, the audit committee, external auditors and other internal and external stakeholders to gather information (Smith, 2005) used to perform internal audit engagements. The subsequent communication of the results of the internal audit engagement to senior management and the board of directors within an organisation is a critical stage in the internal audit process.

The Institute of Internal Auditors (IIA), the global professional body representing the internal audit profession highlights the need for internal auditors to possess excellent communication skills (IIA, 2010). The most recent Common Body of Knowledge (CBOK) study conducted by the IIA Research Foundation in 2010 shows that communication skills are critical in rendering effective services to audit clients. Chief audit executives (the heads of IAFs) as well as internal audit managers ranked effective oral and written communication skills the highest (IIA, 2010) in terms of importance. In addition, the IIA Academic Relations Committee has established an Internal Auditing Educational Partnership (IAEP) programme that highlights the inclusion of business communication as part of the curricula for internal audit students at tertiary institutions (IIA, 2010). However, no guidance is provided in terms of the content, structure or teaching approach to be followed, which was the focus of this study. 
Extensive research has been conducted in the areas of business communication as well as internal auditing and, to a more limited extent, applied business communication skills of internal auditors (Fourie, 2005; Smith, 2005). Prior international research has highlighted the need for both internal and external auditors to enhance their communication skills (Fourie, 2005; PwC, 2013) in order to render an effective value-adding service to organisations. From a South African perspective, the impact of a business communication course for internal audit students at tertiary institutions still represents a relatively unexplored area. Fourie (2005) researched internal auditing and communication and Fourie, Marais and Sadler (2008) reported on the need for technical and behavioural skills of internal auditors in South Africa. Limited literature is available on methods used in higher education to improve the skills of specifically postgraduate auditing students.

In addition, literature on literacy practices for the workplace advocates that communication practices and interventions should not be generic but should emerge from the particular needs and values of the discipline (in this case auditing) (D'Angelo, 2012; Harran, 2011). It is necessary for communicators to learn and understand the cultural and social context within which they will work, before they can produce appropriate discourse (Harran, 2011). It is exactly this context specific nature of the business communication course that was developed that makes the intervention relevant and successful.

In light of the limited research that exists on how to improve the business communication skills of internal audit students, the study that informed this article built on the current body of knowledge and therefore its findings are important from a theoretical perspective. The study could benefit tertiary institutions by providing a framework that can be used for the introduction of an applied business communication course to internal audit students, improving their communication skills and preparing these graduates entering the workforce more successfully (Dana, Hancock \& Philips, 2011). Internal audit lecturers could also use the results of the study to enhance their teaching and assessment practices.

The article is organised as follows: the next section discusses the most pertinent literature with regard to the disciplines and practices of internal auditing and business communication. This is followed by a discussion on the research method and findings. Finally, the conclusions, recommendations and areas identified for future research are presented. 


\section{Literature review}

The concept of business communication is firstly discussed; secondly the relevance of business communication skills to the internal auditor and finally the teaching of business communication in the field of higher education are explored.

\section{Business communication}

Business communication is the process of establishing a common understanding between or among people within a business environment (Williams, Krizan, Logan \& Merrier, 2008). Grant and Borcherds (2008) define communicating at work as the multidirectional and multicultural transactions and interactions that occur within and between business people and/or organisations. These exchanges, whether local or global, interpersonal or electronic, have work-related messages as a core ingredient.

Research among business professionals has revealed that effective communication and interpersonal skills rank very high among the skills necessary to succeed in business (Psenicka; Vendemia \& Kos, 2013; Flosi, Fraccastoro \& Moss, 2010; Halfhill \& Nielsen, 2007; Palmer, Ziegenfuss \& Pinsker, 2004). This is because today's business environment demand of workers to be effective in their fields of expertise as well as in their ability to rally with others to pursue opportunities, solve problems, effect change and manage projects (Adler, 2011, Campbell, 2009). Communicating effectively with colleagues, clients and employees has the advantage of better employee and customer relations, more effective decision making, successful problem solving and increased productivity (Van Staden, Marx \& Erasmus-Kritzinger, 2007). This is also the case for internal audit professionals in the workplace who are continuously engaged in relations with clients, problem solving and reporting on the results of audit assignments to the authorities within an organisation.

\section{Business communication skills for internal auditors}

As mentioned earlier, internal auditors perform internal audit engagements which include planning and conducting the engagement, communicating the results of the engagement to senior management and the board and monitoring whether management has implemented the recommendations made by the IAF (IIA, 2011). The challenge is for the IAF staff to persuade management to incorporate the recommendations made in the internal audit report, which will result in an improvement of organisational operations (IIA, 2011; PWC, 2013). 
The International Standards for the Professional Practice of Internal Auditing (hereafter referred to as the Standards) issued by the IIA, emphasise the fact that "internal auditors must possess the knowledge, skills and other competencies needed to perform their individual responsibilities" (IIA, 2011:19). With reference to communicating the results of an audit engagement, the Standards provide very specific requirements, such as proficiency in interviewing clients, documenting observations and presenting the findings of the audit engagement orally or in writing to internal parties within the organisation (IIA, 2011).

In addition to the Standards, the two most recent global CBOK studies conducted by the IIA Research Foundation in 2006 and 2010 report on the perceptions of chief audit executives, internal auditors and managers on, among others, the competencies needed by internal auditors (IIA, 2010). Communication skills (including oral, written, report writing and presentation) were ranked as the top overall competency for both the 2006 and 2010 surveys. According to the IIA (2010), the reason for the high ranking appears to be the enduring importance of continually developing communication skills from tertiary level through all levels of professional rank. As a result of these CBOK studies, the IIA developed an Internal Auditor Competency Framework which also includes the development of communication skills as a core competency (IIA, 2010).

The above discussion highlights the need for internal auditors to possess excellent communication skills in the workplace. The development of these skills in the form of teaching and training takes place even before prospective internal audit practitioners enter the workplace.

\section{Teaching and training in business communication skills}

The teaching of business communication skills at tertiary level is a common phenomenon (Laster \& Russ, 2010; Newberry \& Conrad, 2010). Various disciplines include business communication knowledge and skills in their curricula at both undergraduate and postgraduate levels. However, the teaching of applied business communication skills at postgraduate level in the discipline of auditing is in most cases insignificant or completely absent (Fourie, 2005). In addition, audit practitioners commented that accounting and auditing trainees entering the workplace are not adequately prepared to communicate with clients, staff and management (Fourie, 2005). Kurtz, Silverman and Draper (2005) comment that even where communication skills programmes have been adopted, they have not always 
been taught effectively. They also state that communication programmes need to produce effective long-lasting changes in students' communication skills (Kurtz et al., 2005).

The question arises as to which teaching methods should be applied to develop the applied business communication skills of postgraduate auditing students about to enter the workplace. The notion of experiential learning is highly relevant to the teaching of business communication and has been explored in several studies (Kolb, 1984; Kolb \& Kolb 2005; Munoz \& Huser, 2008; Goby \& Lewis, 2000). Experiential learning focuses on learning through reflection on one's personal experience, giving students the ability to link concrete experience to theoretical understanding (Biggs, 2003; Kolb \& Kolb, 2005). Furthermore, there is an increasing need for educational institutions to develop those skills and attributes that are required by the industry (Newberry \& Conrad, 2010; Thomas \& Busby, 2003). Collaborative projects, where interdisciplinary university departments and industry professionals meet, create a unique learning opportunity to prepare students for employment (Newberry \& Conrad, 2010; Du-Babcock, 2006).

An enquiry of the status of teaching business communication at tertiary institutions in South Africa presenting internal audit programmes at postgraduate level revealed that only one University, namely the University of Pretoria, has a separate, hands-on applied business communication course (UP, 2010). It therefore appears that there is a lack of collaborative and experiential learning with regard to business communication at tertiary level, thus inadequately preparing internal audit students for the workplace. The study on which this article is based attempted to address this need.

\section{Research methodology}

This article comprises a literature review and an empirical study. The literature review was conducted to examine the disciplines of internal auditing and business communication. The empirical study was conducted over a four-year period (from 2007 - 2010), applying an action research methodology and gathering data from postgraduate internal audit students.

The action research methodology was used to develop a business communication course for postgraduate internal audit students. This methodology was identified as the most relevant methodology for the purpose of this study because the objective of the study was to 
improve/change teaching strategies in auditing. As a strategy, action research is used where the purpose of the study is to promote change and is commonly used by many educationalists to improve their teaching practices (Jove, 2011; Leitch \& Day, 2006; Webb \& Scoular, 2011). Another common theme of action research highlighted by several authors is the process of planning, implementation, observation and evaluation or reflection (Kemmis \& McTaggart, 1988; Noffke \& Stevenson, 1995; O’Hanlon, 1998). These steps were applied in the development and facilitation of the business communication course and are summarised in Table 1.

Table 1: Action research methodology applied for course development

\begin{tabular}{|c|c|c|}
\hline & $\begin{array}{l}\text { Action research } \\
\text { methodology }\end{array}$ & Teachers' actions \\
\hline \multirow[t]{5}{*}{$\begin{array}{l}\text { Years } \\
1 \& 2\end{array}$} & Plan & $\begin{array}{l}\text { The IAEP Advisory Board consisting of internal audit practitioners in } \\
\text { practice and in commerce and industry identified a need to develop a } \\
\text { business communication course for postgraduate internal audit } \\
\text { students. This need was identified in view of the lack of } \\
\text { communication skills among internal auditors entering the profession. } \\
\text { Internal audit lecturers in collaboration with communication } \\
\text { management lecturers developed a postgraduate business } \\
\text { communication course. The purpose of this module is to improve } \\
\text { postgraduate internal audit students' business communication skills. }\end{array}$ \\
\hline & Implement/Act & $\begin{array}{l}\text { The business communication course was presented to postgraduate } \\
\text { students using a conventional teaching approach, namely direct } \\
\text { instruction or lecture-based classes. }\end{array}$ \\
\hline & Observe & Teachers observed the use of direct instruction as a teaching method. \\
\hline & Reflect & $\begin{array}{l}\text { Both teachers and students reflected on the course implemented and } \\
\text { identified a need for improvement and inclusion of an experiential } \\
\text { learning component. }\end{array}$ \\
\hline & $\begin{array}{l}\text { Revised planning and } \\
\text { improvement }\end{array}$ & $\begin{array}{l}\text { Teachers engaged actively. Teachers identified the need to improve } \\
\text { their teaching approach by introducing more unconventional teaching } \\
\text { methods such as a presentations workshop to focus on the } \\
\text { development of oral communication skills. A task force of role-players } \\
\text { was established to brainstorm ideas around suitable teaching strategies } \\
\text { and methods. }\end{array}$ \\
\hline $\begin{array}{l}\text { Years } \\
3 \& 4\end{array}$ & Implement/Act & $\begin{array}{l}\text { Teachers developed a presentations workshop and introduced the } \\
\text { workshop as part of a new teaching-learning method in facilitating a } \\
\text { business communication course to postgraduate internal audit } \\
\text { students }\end{array}$ \\
\hline
\end{tabular}




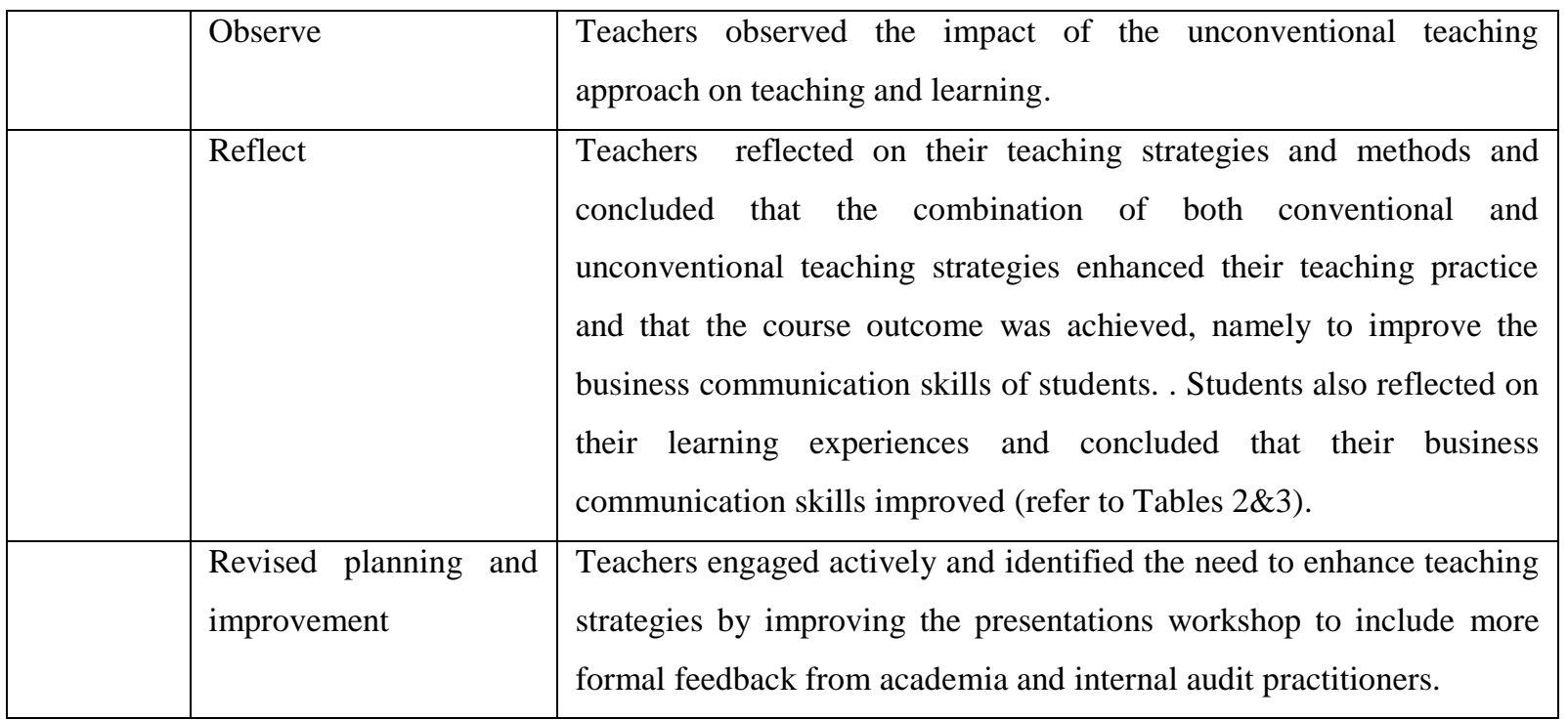

As part of the action research methodology, after implementation of the intervention, namely the business communication course students reflected on their learning experiences. Feedback from the students was received from two sources, namely the Student Feedback Instrument: Teaching and Assessment (SFI), completed from 2007 to 2010, and a presentations workshop survey that was completed in 2009 and 2010. In line with action research methodology, the action research project, namely the Business Communication Management (BCM) course will firstly be discussed, followed by the findings.

\section{Action research project}

The need for developing the business communication competencies of internal auditors at tertiary level was identified by the Advisory Board of the University of Pretoria Internal Auditing Educational Partnership (IAEP) programme presented by the Department of Auditing in 2006 (refer to Table 1). The IAEP Advisory Board suggested the introduction of a business communication course at postgraduate level for internal audit students. A task force consisting of academics and internal audit practitioners was established to investigate the structure and content of such a business communication course. This led to the introduction of the BCM course in 2007, exclusively developed for postgraduate internal audit students. The team of lecturers involved in the development of the BCM course received a Laureate Award from the Department for Education Innovation at the University of Pretoria based on the criterion that the course is based on exceptional and innovative 
instructional practices that respond to the teaching and learning challenges within the UP learning environment and beyond (UP, 2010).

The reason for introducing the business communication course to postgraduate internal audit students was two-fold: firstly to address the need identified in the workplace for professional internal auditors with excellent communication skills (as evident in the literature review) and secondly to improve the business communication competencies of postgraduate internal audit students.

The BCM course is a combination of conventional teaching and experiential learning. Experiential learning was brought into the course to balance the process of passive learning that is mostly facilitated by lecture-based classes (Kolb, 2005; Munoz \& Huser, 2008). During the lecture-based classes, various verbal and non-verbal communication concepts are dealt with that can be grouped in three main areas, namely interpersonal communication, written communication and presentations skills. These areas with their underpinning philosophy are summarised in Table 2.

Table 2: Results of the Student Feedback Instrument: Teaching and Assessment

\begin{tabular}{|l|l|l|l|l|}
\hline \multicolumn{5}{|c|}{ Likert scale (1 - poor; 5-excellent) } \\
\hline & $\mathbf{2 0 0 7}$ & $\mathbf{2 0 0 8}$ & $\mathbf{2 0 0 9}$ & $\mathbf{2 0 1 0}$ \\
\hline $\boldsymbol{n}$ & 44 & 64 & 72 & 64 \\
\hline Response rate: & $63 \%$ & $82 \%$ & $83 \%$ & $83 \%$ \\
\hline Teaching & 4.5 & 4.6 & 4.5 & 4.5 \\
\hline Professionalism & 4.6 & 4.7 & 4.5 & 4.5 \\
\hline Facilitation of learning & 4.4 & 4.6 & 4.4 & 4.5 \\
\hline Assessment & 4.4 & 4.5 & 4.3 & 4.5 \\
\hline Average & $\mathbf{4 . 5}$ & $\mathbf{4 . 6}$ & $\mathbf{4 . 4}$ & $\mathbf{4 . 5}$ \\
\hline
\end{tabular}

In addition to the lecture-based classes, a three-day presentations workshop is presented providing students the opportunity to practise and improve their presentation skills, to study a number of internal audit topics and to enhance their teamwork skills. A collaborative approach is followed during the workshop, involving internal audit practitioners, academia and representatives from the professional body to provide immediate feedback to the students. Assessment is done continuously to test students' knowledge and skills with reference to the areas indicated in Table 2. This inviting engagement of a learning community 
is of utmost importance for the successful execution of the entire course and ultimately the teaching and learning experiences to follow.

\section{Findings}

The feedback obtained from the students, are subsequently discussed.

\section{Feedback 1 (students: UP SFI)}

The SFI reflects students' overall impression of the course, with the focus on teaching, professionalism, facilitation of learning and assessment. The results from 2007 to 2010 are depicted in Table 3.

Table 3: Results of the Presentations Workshop evaluation 2009 and 2010

\begin{tabular}{|l|l|l|}
\hline \multicolumn{2}{|c|}{ Likert scale: (1 - strongly disagree; 5 - strongly agree) } & $\mathbf{2 0 1 0}$ \\
\hline $\boldsymbol{N}$ & $\mathbf{8 3}$ & $\mathbf{7 1}$ \\
\hline Response rate & $\mathbf{9 5 \%}$ & $\mathbf{9 5 \%}$ \\
\hline The workshop improved my confidence as a speaker. & 4.3 & 4.4 \\
\hline The workshop improved my presentation skills. & 4.5 & 4.4 \\
\hline The comments from the panel were valuable. & 4.5 & 4.5 \\
\hline I learned a lot by evaluating my fellow students. & 4.2 & 4.1 \\
\hline The internal audit topics made a valuable contribution to my career knowledge. & 3.9 & 4.1 \\
\hline
\end{tabular}

From the results presented in Table 3 it is clear that over the past four years students consistently experienced the BCM course very positively. The results provide concrete and quantified evidence that the students agree that the BCM course offers excellent teaching, professionalism, facilitation of learning and assessment standards. A possible explanation for the positive results in Table 3 is that the course was designed and executed according to the same high standards that are advocated as a requirement for the students to be successful in their professional careers.

\section{Feedback 2 (students: presentations workshop survey)}

The presentations workshop survey reflects the students' feedback of their experience of the three-day presentations workshop. To determine whether the presentations workshop 
objectives, namely to practise and improve presentation skills, to study internal audit topics and to enhance teamwork skills had been achieved, students were asked to complete an anonymous evaluation sheet at the end of the 2009 and 2010 presentations workshops (as a new intervention to the BCM course, formal feedback was only obtained from 2009

Table 4: Grouping of concepts and the underpinning philosophy

\begin{tabular}{|c|c|c|}
\hline Area & Concepts & Philosophy \\
\hline $\begin{array}{l}\text { Interpersonal } \\
\text { communication }\end{array}$ & $\begin{array}{l}\text { Intrapersonal communication, personal } \\
\text { branding, emotional intelligence, whole- } \\
\text { brain thinking, intercultural } \\
\text { communication, small groups, meeting } \\
\text { procedure and protocol, business } \\
\text { etiquette }\end{array}$ & $\begin{array}{l}\text { This area of communication deals with the } \\
\text { person behind the message (sender and } \\
\text { receiver). This requires an understanding } \\
\text { of the messages to yourself, understanding } \\
\text { your preferred communication style and } \\
\text { respecting the style of others. Dealing } \\
\text { with your own perceptions and those of } \\
\text { others. This area also sensitizes students } \\
\text { for the specific business protocol } \\
\text { expectations for internal audit } \\
\text { professionals, inter alia dress code and } \\
\text { company culture (Bass, 2010; Halfhill \& } \\
\text { Nielsen, 2007; Palmer et al. 2004). }\end{array}$ \\
\hline $\begin{array}{l}\text { Written } \\
\text { communication }\end{array}$ & $\begin{array}{l}\text { Effective vocabulary; } \\
\text { Readability, spelling and grammar, style, } \\
\text { tone, jargon report writing and graphics. }\end{array}$ & $\begin{array}{l}\text { Business people are overloaded with } \\
\text { communication messages. In order to } \\
\text { make messages stand out, written } \\
\text { messages should be to the point and } \\
\text { concise but also ensure that good will is } \\
\text { displayed (Sladoljev-Agejev, 2008; } \\
\text { Spigelman, \& Grobman, 2006; Smith, } \\
\text { 2005). }\end{array}$ \\
\hline Presentations skills & $\begin{array}{l}\text { Planning, crafting and delivery of } \\
\text { presentations. The use of visual aids such } \\
\text { as PowerPoint. }\end{array}$ & $\begin{array}{l}\text { The ability to do oral presentations that } \\
\text { will make an impact and increase the } \\
\text { credibility of the internal audit team with } \\
\text { management has been recognised by the } \\
\text { internal audit profession (Coetzee, Du } \\
\text { Bruyn, Fourie \& Plant, 2010; Smith, } \\
\text { 2005). }\end{array}$ \\
\hline
\end{tabular}

onwards). The survey was developed to specifically test the students' perceptions of the impact that the three-day workshop had on developing their communication skills and their knowledge of internal auditing topics. The survey also tested how the students perceived the 
comments from the panel and whether or not they found it valuable to peer review their fellow students' presentation skills during the workshop. The results of the 2009 and 2010 evaluations are shown in Table 4.

Table 4 shows that the BCM students of 2009 and 2010 either agreed or strongly agreed that the presentations workshop improved their confidence as speakers and improved their presentation skills. They strongly agreed that the comments from the panel were valuable. They also agreed or strongly agreed that they had learned a great deal from evaluating their fellow students and that the internal audit topics made a valuable contribution to their knowledge. The positive results in Table 4 can be attributed to the joint and focused efforts by the students, academic and administrative staff as well as the internal audit practitioners.

Lastly, the survey prompted the students to indicate what they liked most about the workshop and what they liked least. They could also make suggestions to improve future workshops. The responses to these open-ended questions clearly showed that they found the presentations workshop invaluable to improving their presentation skills. A comparison between the feedback in 2009 and 2010 indicates that the students generally appreciated the opportunity to get to know their fellow students better and to work together in teams. From the feedback it was clear that the students learned a lot from listening to and evaluating each other. They also welcomed the constructive criticism and valuable comments from the panel on their presentation skills. The students perceived the workshop to be a great learning experience that improved their presentation skills, although it was tiring and intimidating at times. Some indicated that the workshop helped them to overcome their fear to speak in public and for some it increased their confidence to do presentations.

\section{Conclusions and recommendations}

The study on which this article is based makes an initial attempt to determine the impact of introducing a business communication course into curricula for postgraduate internal audit students, a relatively unexplored area. The need for internal audit practitioners to possess excellent communication skills was highlighted in the literature review. Developing business communication skills at tertiary level was also identified as a need and briefly explained. An intervention, namely a business communication course for internal audit students was 
developed and introduced to address these needs. Feedback was subsequently obtained from the students to determine the impact of the intervention on their learning experiences.

Results from the students' feedback show that the postgraduate internal audit students experience the Business Communication Management (BCM) course very positively and that the course contributes to improving their communication skills. From the analysis of the results, it can be concluded that the introduction of a business communication course into the curriculum of postgraduate internal audit students is a highly beneficial learning activity in improving business communication skills at tertiary level. This study also strengthens the argument as mentioned in the literature review for communication interventions that take the particular communication norms of a discipline into account.

The limitation of the study is the fact that formal feedback was only received from the students. Limited formal feedback was received from the lecturers and internal audit practitioners. However, studying and reporting on the reflections from both these stakeholders, is an area for future research. Replicating this intervention at other tertiary institutions and studying the impact on teaching and learning, is also a future research possibility.

It is recommended that tertiary institutions should consider including a business communication course into the curricula of postgraduate internal audit students. The Institute of Internal Auditors (IIA) could also consider adapting its Internal Auditing Educational Partnership (IAEP) programme's proposed syllabus for tertiary institutions to include an applied business communication course. Internal audit practitioners can also present the BCM course to internal audit staff entering the profession. Enhancing the business communication competencies of internal audit students and ultimately internal audit professionals will contribute to the IAF adding value and improving an organisation's operations.

\section{Notes on contributors}

Both authors are lecturers in the Faculty of Economic and Management Sciences, University of Pretoria, South Africa.

Kato Plant is a lecturer in Internal Auditing. She is passionate about internal audit education and workplace learning and her areas of specialisation also include organisational governance and ethics as well as professional ethics. 
Jana Slippers is a lecturer in Business Communication. She helps to prepare internal auditing honours students to communicate professionally. She also presents courses in Business Communication to professionals in the corporate sector. She enjoys interdisciplinary research and teaching opportunities.

\section{References}

Adler, G. (2011). Financial Times Briefings: Management communication. Prentice Hall, Financial Times.

Bass, A.N. (2010). From business dining to public speaking: Tips for acquiring professional presence and its role in the business curricula. American Journal of Business Education, 3(2)pp.57-pp.63.

Biggs, J.B. 2003. Aligning teaching and assessing to course objectives. Retrieved May 27, 2012 from: http://www.josemnazevedo.uac.pt/proreitoria/docs/biggs.pdf

Campbell, M. (2009). Communication skills for project managers. New York, AMACOM.

Coetzee, G.P., Du Bruyn, R. Fourie, H. \& Plant, K. (2010). Advanced Internal Audit Topics Durban: LexisNexis.

Dana, H., Hancock, C. \& Phillips, J. (2011). The future of business: Merit in writing across the curriculum. American Journal of Business Education, 4(10):pp.51-pp.58.

D’Angelo, B. (2012). Student learning and workplace IL: A case study. Library Trends, 60(3): pp.637-pp.650.

Du-Babcock, B. (2006). Teaching Business Communication. Journal of Business Communication, 43(3): pp.253-pp.264.

Flosi, A., Fraccastoro, K. \& Moss, G.J. (2010). Cross-course projects: Teaching students on changing business communication methods. American Journal of Business Education, 3(1), pp.65-pp.70.

Fourie, H. (2005). Internal Auditing and Communication: A South African perspective. (Unpublished master's thesis). Tshwane University of Technology, South Africa. 
E. Sadler, M. Marais, H. Fourie, (2008) Internal auditors' compliance with the IIA Standards: a worldwide perspective, Meditari Accountancy Research, 16(2), pp.123 - pp.138.

Goby, V.P. \& Lewis, J.H. (2000). Using Experiential Learning Theory and the Myers-Briggs Type Indicator in teaching Business Communication. Business Communication Quarterly, 63(3), pp.39-pp.48.

Grant, T \& Borcherds, R. (2008). Communicating @ Work: Boosting your spoken,written and visual impact. Second Edition. Van Schaik: Pretoria.

Halfhill, T.R. \& Nielsen, T.M. (2007). Quantifying the "softer side" of management education: an example using teamwork competencies. Journal of Management $\quad$ Education, 31(1), pp.64-pp.pp.80.

Harran, M. (2011). Dominant feedback practices: shaping engineer literacy perceptions. Journal of Engineering, Design and Technology, 9(11), pp.85-pp.109.

IIA (Institute of Internal Auditors). (2009). Definition of internal auditing. Retrieved May 27, 2012 from: http://www.theiia.org/guidance/standards-and guidance/ippf/definition- ofinternal-auditing.

IIA (Institute of Internal Auditors). (2010). Competencies for today's internal auditor. Institute of Internal Auditors: Alamonte Springs.

IIA (Institute of Internal Auditors). (2011). International Professional Practices Framework Institute of Internal Auditors: Alamonte Springs.

Jove, G. (2011). How do I improve what I am doing as a teacher, teacher educator and actionresearcher through reflection? A learning walk from Lleida to Winchester and back again. Educational Action Research, 19(3):261-278.

Kemmis, S., \& McTaggart, R. (1988). The action research planner (3rd ed.).Victoria, Australia: Deakin University Press.

Kolb, D.A. (1984). Experiential learning: Experience as the source of learning and development. Englewood Cliffs, NJ: Prentice Hall. 
Kolb, A.Y. \& Kolb, D.A. (2005). Learning styles and learning Spaces: Enhancing experiential learning in higher education. Academy of Management Learning and Education Journal, 4(2), pp.193-212.

Kurtz, S, Silverman, J \& Draper, J. (2005). Teaching and Learning Communication Skills in Medicine. Second Edition. Radcliffe Publishing: Oxford.

Laster, N.M. \& Russ, T.L. (2010). Looking Across the Divide: Analyzing Cross-Disciplinary Approaches for Teaching Business Communication. Business Communication Quarterly, 73(3), pp.248-pp.264.

Leitch, L. \& Day, C. 2006. Action research and reflective practice: towards a holistic view. Educational Action Research, 8(1):179-193.

Munoz, C. \& Huser, A. (2008). Experiential and Cooperative Learning: Using a Situation Analysis Project in Principles of Marketing. Journal of Education for Business, March/April, pp.214-pp.220.

Newberry, R. \& Conrad, D. (2010). Identification of outcome based business communication skills. Proceedings of the Academy of Organizational Culture, Communication and Conflict, 15(2), pp.28-pp.32.

Noffke, S.E., \& Stevenson, R.B. (Eds.). (1995). Educational action research: Becoming practically critical. New York: Teachers College Press.

O’Hanlon, C. (Ed.). (1996). Professional development through action research in educational settings. Washington, DC: Falmer Press.

Palmer, K.N., Ziegenfuss, D.E. \& Pinsker, R.E. (2004). International knowledge, skills, and abilities of auditors/accountants. Managerial Auditing Journal, 19(7), pp889-pp.896.

Psenicka, C., Vendemia, W. \& Kos, A. (2013). The impact of grade threat on the effectiveness of peer evaluations of business presentations: an empirical study.

International Journal of Management, 30(1), pp.168-pp.174. 
PwC (Pricewaterhousecoopers) (2012). The state of the internal audit profession. Retrieved May 27, 2012 from: http://www.pwc.com/

Sladoljev-Agejev, T. (2008). Effective written communication as a competitive advantage on the labour market: Enhancing business curricula with report writing skills. An Enterprise Odyssey. International Conference Proceedings: pp.443-pp.453. Zagreb: University of Zagreb, Faculty of Economics and Business, (Jun 11-Jun 14)

Smith, G. (2005). Communication skills are critical for internal auditors, Managerial Auditing Journal, 20(5): pp.513-pp.519.

Spigelman, C. \& Grobman, L. (2006). Why we chose rhetoric: Necessity, ethics, and the (re)making of a professional writing program. Journal of Business and Technical Communication, 20(1):pp.48-pp.64.

Thomas, S. \& Busby, S. (2003). Do industry collaborative projects enhance students' learning? Education \& Training, 45(4): pp.226-pp.235.

UP (University of Pretoria). (2010). Laureate award for innovative teaching practices presented to the Department of Auditing in collaboration with the Department of Communication Management. Pretoria: University of Pretoria.

Van Staden, E, Marx, S \& Erasmus-Kritzinger, L. (2007). Corporate Communication: Getting the message across in business. Second Edition. Van Schaik: Pretoria.

Webb, L.A. \& Scoular, T. 2011. Reflection on reflection on reflection: collaboration on action research. Educational Action Research, 19(4): 469-487.

Williams, K. Krizan, A.C., Logan, J. \& Merrier, P. (2008). Communicating in Business. Eighth Edition. South-Western: Cengage Learning. 